\title{
Zofia Szarota
}

Uniwersytet Pedagogiczny im. Komisji Edukacji Narodowej w Krakowie

\section{„Czuję się jak eksponat..." - rozmowa z Profesorem Tadeuszem Aleksandrem \\ "I feel like an exhibit" - a conversation with Professor Tadeusz Aleksander}

\begin{abstract}
Streszczenie. Artykuł poświęcony jest sylwetce Tadeusza Aleksandra, jednego z czołowych polskich pedagogów i andragogów, uczonemu, który swą osobowością odcisnął pozytywne piętno na wielu rocznikach studentów Uniwersytetu Jagiellońskiego, Wyższej Szkoły Biznesu i Przedsiębiorczości w Ostrowcu Świętokrzyskim, Krakowskiej Akademii im. Andrzeja Frycza Modrzewskiego, a ostatnio Wszechnicy Polskiej Szkoły Wyższej w Warszawie. W przedstawianej opowieści autobiograficznej Profesor dzieli się wspomnieniami o swoim pochodzeniu, o doświadczeniach z lat szkolnych i studiów. Przywołuje pierwszą pracę zawodową. Wspomina swoich mentorów, opowiada o zainteresowaniach. Skromnym milczeniem pomija informacje o licznych sukcesach i dokonaniach, przyznanych nagrodach, zaszczytach i wyróżnieniach. Dzieli się refleksją o tym, co w życiu najważniejsze - zdrowa rodzina, pracowitość, sumienność i odporność na niekorzystne zewnętrzne uwarunkowania.
\end{abstract}

Słowa kluczowe: autobiografia, kariera uczonego, zdarzenia krytyczne, doświadczenie, mądrość

Summary. The article is dedicated to the personage of Tadeusz Aleksander, one of the leading Polish educators and andragogues, a scholar whose personality has left a positive mark on many students of Jagiellonian University, College of Business and Entrepreneurship in Ostrowiec Świętokrzyski, Andrzej Frycz Modrzewski Krakow University, and Wszechnica Polska University in Warsaw. In the autobiographical story, he shares with his former student memories of his origin, experiences of school years and studies. He recalls his first professional work. He mentions his mentors, tells about his interests. With abstemious silence he omits information about numerous successes and achievements, awarded prizes, and honors. He shares the reflection on what is most important in life - healthy family, hard work, diligence and resistance to unfavorable external conditions.

Key words: autobiography, career of a scholar, critical incidents, experience, wisdom. 


\section{Biograficzna nota}

Profesor zw. dr hab. Tadeusz ALEKSANDER, ur. 10 października 1938 r. we Frycowej koło Nowego Sącza. Całe zawodowe życie związany był z Uniwersytetem Jagiellońskim (początkowo Wydział Filozoficzno-Historyczny, a od 1992 r. - Wydział Filozoficzny). Zajmował się problematyką różnorakiej aktywności ludzi dorosłych (poznawczej, zawodowej, społecznej, kulturalnej). Odbudował (1981 r.) krakowski Oddział Polskiego Towarzystwa Pedagogicznego i był jego pierwszym przewodniczącym. Współzałożył Akademickie Towarzystwo Andragogiczne (1993 r.) i był jednym z jego wiceprezesów. Przez wiele lat członek Rady Naukowej Towarzystwa Wiedzy Powszechnej. Wchodził w skład Komitetu Nauk Pedagogicznych PAN. W latach 2003-2011 przewodniczący Zespołu Pedagogiki Dorosłych w tym Komitecie. Pomysłodawca i organizator pierwszego Ogólnopolskiego Zjazdu Andragogicznego (Kraków, 23-24 czerwca 2009 r.).

Autor podręcznika Andragogika (2013, wyd. 2, ss. 460), 14 monografii (w tym źródłowego studium Życie społeczne i przemiany kulturalne Nowego Sacza w latach 1870-1990, ss. 856) i ponad 350 publikacji mniejszych (rozprawy i artykuły naukowe, komunikaty z badan, ekspertyzy, recenzje opublikowanych książek i in.) traktujących o różnych zagadnieniach teorii i praktyki kształcenia dorosłych, dziejów pracy oświatowej oraz przeszłości miejscowości i ludzi (głównie z regionu sądeckiego).

Przez wiele lat nauczyciel akademicki, promotor ponad 830 prac magisterskich i 13 doktorskich, wymagający recenzent, życzliwy krytyk ocenianych prac naukowych.

Entuzjasta wycieczek krajoznawczych i turystyki.

Droga Pani Profesor, nie spodziewałem się, że mnie tak szybko czas minie i że ktoś będzie mi „wypominał” mój wiek. Nie myślałem, że ktoś zechce poznać niełatwą historię mojego życia. To zainteresowanie traktuję jako karę za wybryk, jakiego dopuściłem się w dzieciństwie. Uczyłem się od 1945 r. w szkółce wiejskiej, początkowo o dwu nauczycielach. Było to w Porębie Małej koło Nowego Sącza (dzisiaj Mała Poręba - bo tak ją z czasem nazwano jest zamożnym, dynamicznie rozwijającym się południowym osiedlem Nowego Sącza z okazałym budynkiem szkolnym - szkoły $\mathrm{nr} 17$, autobusem MPK, nowym kościołem parafialnym i wszystkimi elementami miejskiej infrastruktury). We wrześniu 1948 r., gdy rozpoczynałem naukę w czwartej 
klasie, J.J. - ówczesna kierowniczka szkoły - wprowadziła i uroczyście przywitała nowego nauczyciela - W.T. Był nim przystojny, szczupły i starannie ubrany, całkiem starszy mężczyzna z burzą siwych włosów na głowie. $\mathrm{Na}$ jego widok wrzasnąłem do stojącego obok kolegi: „Ale siwula!”. To przezwisko „przykleiło” się na stałe do tego doskonałego i przyjaznego dzieciom nauczyciela, wychowanka starosądeckiego seminarium nauczycielskiego z czasów austriackich. Dzisiaj mam taki sam kolor włosów. Ludzie są grzeczni, koloru tego mi nie wypominają. Coraz częściej jednak wskazują na mój wiek, co traktuję jako zaległą „zemstę” za wybryk.

\section{Rodowód}

Nie da się ukryć, że pochodzę z rodziny józefińskich osadników. Gdy po I rozbiorze Polski (1772 r.) Austria wcielała w swój organizm państwowy (a nie wszyscy wiedzą, że Spisz, ziemia sądecka i nowotarska zagrabione zostały przez wojska cesarzowej Marii Teresy już w 1770 r.) południowe ziemie Rzeczypospolitej Polskiej, Józef II Habsburg, następca wiedeńskiego tronu, kilkakrotnie zwiedzał pozyskaną prowincję. Uderzyło go w niej ogromne zaniedbanie gospodarcze i przerażające ubóstwo ludności chłopskiej. Dostrzegał też źródło tej sytuacji w stosunkach pańszczyźnianych i eksploatacji chłopów przez szlachtę oraz pobliskie klasztory. By temu zaradzić - już jako cesarz Austrii (1780-1890), noszący zarazem tytuł władcy Świętego Cesarstwa Rzymsko-Niemieckiego - reformując kraj zlikwidował około 800 klasztorów kontemplacyjnych („próżniaczych”), a na pozostawione po nich dobra ziemskie sprowadził w latach 1782-1785 do Galicji głównie z Palatynatu około 1000 starannie dobranych rodzin: złożonych z ludzi młodych i gospodarnych, wychowanych w tradycji rzetelnej niemieckiej pracy. Na miejscu, w Galicji rodziny te uzyskały rządową pomoc w zagospodarowaniu się, dzięki czemu stały się stymulatorem rozwoju gospodarczego i społecznego wielu zasiedlonych miejscowości. W tych warunkach do Załubińcza (dzisiaj północne osiedle Nowego Sącza) przybył z miejscowości Kalkofen Johan Adam Aleksander (1751-1825) z żoną Marianną i pięcioma synami. Za przywiezione z sobą oszczędności od miejscowej administracji zakupił podupadający dwór w Załubińczu (dawną królewszczyznę) o nazwie „Wierzbięcińskie”. Zamieszkał w nim z rodziną, zamieniając należące do dworu nieużytki w dobrze prosperujące gospodarstwo. W Załubińczu jego rodzina powiększyła się o następnych trzech synów. To oni w wieku męskim zakładając rodziny przenosili się do różnych miejscowości Sądecczyzny, stając się protoplasta- 
mi spolonizowanej i rozgałęzionej familii. Jej członkowie, dzięki wykształceniu i sporej pracowitości, zajmowali różne stanowiska i bogacili się, jak np. wnuk Johana Adama, Józef Aleksander (1821-1877). W wieku 13 lat ukończył nowosądeckie gimnazjum po czym studia w Cesarsko-Królewskim Instytucie Politechnicznym, a następnie w Cesarskiej Akademii Połączonych Sztuk w Wiedniu, po czym pracował jako inżynier budowlany w nowosądeckim Urzędzie Cyrkularnym (urzędowi podlegało 10 powiatów). Ożeniony z Herminą Genersich węgierskiego pochodzenia (siostra Antona Genersicha, rektora uniwersytetów w Kluj i Budapeszcie), dbał o warunki materialne szóstki swoich dzieci, kształcąc je i osadzając na zakupionych przez siebie następnych nieruchomościach (jego najstarszy syn Konrad w latach 1897-1909 był zastępcą burmistrza Nowego Sącza).

Szanowna Pani Profesor, mógłbym dalej snuć relacje o rozwoju mojej rodziny w przeszłości, kształceniu i stanowiskach zajmowanych przez jej członków. Nie jest to potrzebne ani interesujące. Poinformuję Panią jedynie o tym, że dobre czasy mojej dużej familii zakończyły się z chwilą wybuchu II wojny światowej. W czasie jej trwania kilku zawodowych wojskowych z rodziny poległo (Arminiusz w Palestynie jako podoficer w Armii Andersa). Dwie rodziny przeżywały długotrwałą trwogę w związku z pomocą Żydom. U inż. Alfreda Aleksandra, mieszkającego w bezpośrednim sąsiedztwie koszar Wehrmachtu, przez całą wojnę przechowała się młodziutka Zula Grossbard (po wojnie lekarka na Opolszczyźnie). Jadwiga Aleksandrowa z Krasnego Potockiego (mąż Bronisław został rozstrzelany we wrześniu 1939 r.), używając podstępu wyprowadziła z sądeckiego getta rodzinę Emila Steinlaufa i pomogła jej w przetrwaniu wojny w kryjówce urządzonej w sąsiedztwie swoich dóbr (do jej dworu często przyjeżdżały patrole niemieckie). Prawdziwy dramat rodziny zaczął się jednak po zakończeniu wojny w czasie realizacji reformy rolnej i nacjonalizacji ziemi. Podam przykłady z najbliższego kręgu rodzinnego. Obaj bracia mojego dziadka, pracowici ziemianie (wychowankowie szkoły rolniczej w Czernichowie i ochotnicy z wojny 1920 r.), utracili majątki ziemskie, a ich rodziny zostały wyrzucone $z$ domu. Uratowały się jedynie dobra ziemskie mojego dziadka Antosia, a to dzięki temu, że jeszcze przed wybuchem II wojny podzielił je (równo) pomiędzy dziewięcioro swoich dzieci (trzy córki i sześciu synów), tworząc z tak rozdysponowanego majątku drobne gospodarstwa. 


\section{Dom, dzieciństwo}

Pani Profesor, wychowałem się w warunkach wyjątkowej powojennej biedy we wspomnianej Porębie Małej, dokładnie 6 kilometrów od sądeckiego ratusza. Z położonego na wzniesieniu ogrodu dziadka Antosia widać było w dole, jak na dłoni, centrum Nowego Sącza. Miałem młodych rodziców, na dorob$\mathrm{ku}$ (ojciec siłami rodziny przez lata budował dom z materiału zdobywanego z ogromnym trudem). Byłem najstarszy z czwórki braci. Miejscowość była wyjątkowo zaniedbana: nieutwardzone, błotniste drogi, brak elektryczności (zelektryfikowano ją w 1957 r.), zabudowania w większości z drewna. Jednym: słowem spadek po - opisanej w literaturze naukowej (S. Szczepanowski, Nędza Galicji w cyfrach...,1888) - galicyjskiej biedzie. To środowisko uczyło jednak zaradności, pracowitości i oszczędności, a nade wszystko poszanowania tego, co się zdobyło. Dodam jeszcze, że moje dzieciństwo przypadło na bardzo trudną sytuację polityczną lat powojennych. Patriotycznie wychowana miejscowa ludność z rezerwą odnosiła się do nowego narzuconego nam ustroju. Stan ten utrwaliła tragedia miejscowej rodziny Mizgałów. Po wojnie w nowosądeckich koszarach stacjonowało wojsko rosyjskie. Z początkiem lipca 1945 r. na terenie Poręby Małej zjawił się żołnierz rosyjski i przypuszczam, że w celach aprowizacji dla wojska - chciał odebrać jedyną krowę - jak się zwyczajowo mówiło: żywicielkę rodziny - miejscowej wdowie z trojką dzieci (córka owej wdowy, Irka, nieco później chodziła ze mną do szkoły podstawowej). Zdeterminowana, rosła wdowa chwytem za kosę przepędziła intruza. $\mathrm{W}$ dniu następnym intruz powrócił konno $z$ dwoma uzbrojonymi kolegami w celu odwetu. Pomylił jednak domostwo. Weszli do sąsiedniego domu Mizgałów i seriami z karabinu zastrzelili ciężarną 41-letnia matkę Stefanię i jej trójkę dzieci w wieku od 14-19 lat. Tragedię przeżyły 6-letnia Teresa (chodziłem z nią do jednej klasy szkoły podstawowej) i 2,5-letnia Stefania, które w momencie wkroczenia do domu obcych ukryły się za drzwiami pokoju. Ojciec rodziny Antoni (46 lat), były żołnierz I Pułku Strzelców Podhalańskich, i najstarszy syn Franciszek (21 lat) byli wtedy w pracy. Zbiorowa interwencja przedstawicieli miejscowej ludności (był tam i mój ojciec) w sądeckim dowództwie wojsk rosyjskich nic nie dała (wykryto sprawców jedynie po dojściu do tego, kto „zajechał” zmęczone i rozdrażnione konie). Ludność Poręby Małej licznie uczestniczyła w zbiorowym pogrzebie Mizgałów na cmentarzu parafialnym w Żeleźnikowej. Ta zbrodnia położyła się cieniem na stosunku miejscowej ludności do Rosjan. Zrozpaczony Franciszek niedługo po tym wstąpił do Polskiej Podziemnej Armii Niepodległościowej. W 1949 r. poległ w czasie obławy zorganizowanej przez 
UB. Trzeba też powiedzieć o echach akcji „Wisła” w moim środowisku: wysiedlaniu Łemków z niedalekich wsi, szabrze tego (łącznie z cerkiewkami), co po nich zostało, żywiołowym zasiedlaniu opuszczonych przez nich domostw niejednokrotnie przez ludzi wątpliwej proweniencji. Obserwowanie tego zaskakiwało wielu ludzi i podważało ich system aksjologiczny, nie robiło na pracowitej miejscowej ludności mojego środowiska dobrego wrażenia. Złożoność sytuacji politycznej w wymienionym środowisku tamtych lat pogłębiła się z chwilą powstania w 1947 r. w górzystym i zalesionym rejonie sąsiedniej Nawojowej wspomnianej Polskiej Podziemnej Armii Niepodległościowej (dziś zaliczanej do Żołnierzy Wyklętych). Założycielem i dowódcą organizacji był Stanisław Pióro, leśnik z Nawojowej, kolega mojego ojca. Pamiętam jak w latach 1947-1949 ludzie z oddziału PPAN, a było ich sporo, przychodzili do ojca i mówiąc mu po imieniu pytali, czym ich może wesprzeć. Co otrzymywali i ile - tego nie wiem. Wiem natomiast, że w dzień przyjeżdżali do nas wojskowym „łazikiem” zbrojeni funkcjonariusze UB i długo przesłuchiwali ojca na temat tego, kto i w jakim celu do niego w nocy przychodził. Ojciec - jak zwykle - nic „nie wiedział” i „nie widział”. Zgrupowanie PPAN S. Pióry zostało w 1949 r. rozbite przez oddziały UB S. Wałacha (autora kłamliwej książki Był w Polsce czas, 1969) w dwu zasadzkach. Echa pierwszej, na górze w Kunowie, z lipca 1949 r. brzmią mi do w uszach do dzisiaj w postaci „szelestu” karabinów maszynowych.

Droga Pani Profesor, pyta Pani o dom rodzinny. Z bardziej interesujących $w$ nim rzeczy z dzieciństwa pamiętam częste rozmowy rodziców między sobą, z sąsiadami i gośćmi, a później gdy dorastaliśmy - z nami, synami. Dwa tematy tych rozmów dominowały. Jeden podejmowany przez matkę, a drugi przez ojca. Ulubioną treścią opowiadań matki były dzieje i życie rodziny hr. Stadnickich z sąsiedniej Nawojowej. Matka - pochodząca z wielodzietnej rodziny, bardzo dobra uczennica Szkoły Powszechnej i jakiegoś kursu u tamtejszych dominikanek - pracowała u Stadnickich bezpośrednio opiekując się ks. Heleną Sapieżanką z Krasiczyna, matką hr. Adama Zbigniewa Leona Stadnickiego. Poznała tam wszystkich członków tej wybitnej rodzin,y w tym i księcia kardynała Adama Sapiehę. Później, przez całe swoje życie, wspominała ludzi z tej rodziny, ich wykształcenie, zajęcia, sposób zachowania i tragiczne wypędzenie z pałacu w 1945 r. Dla odmiany tematem częstych opowiadań ojca była wrześniowa (1939) „uciekinierka”. W miejscu mojego urodzenia w pierwszych dniach tragicznego września pojawiła się pogłoska o mordowaniu młodych mężczyzn przez Niemców i rzekomym nakazie władz polskich wymarszu mężczyzn na Wschód, gdzie zostaną uzbrojeni i będą mogli walczyć z najeźdźcą. Ojciec i jego młodszy brat August ulegli 
tej pogłosce i w niewyobrażalnych warunkach popłochu i dramatu „uciekinierów" po trzech tygodniach (22 września) dotarli pieszo do zajmowanego przez Armię Czerwoną Lwowa. Unikając kolejnych zagrożeń, również w bardzo trudnych warunkach (dla bezpieczeństwa nocowali na cmentarzach), po kolejnych dwu tygodniach wycieńczeni powrócili do domu. Całe życie ojciec opowiadał o dramacie tej „uciekinierki”: o chaosie komunikacyjnym na drogach, ataku niemieckiego lotnictwa na skupiska bezbronnej ludności, rozbitych oddziałach wojskowych - bez dowództwa i amunicji, zniszczeniach poszczególnych miast i osiedli, poległych i rannych żołnierzach, braku żywności i wody pitnej, studniach z napisem „woda zatruta”, zachowaniu się nacjonalistów ukraińskich i in.

W opisywanych warunkach rodzinnej biedy i trwogi, we wrześniu 1945 r. rozpocząłem naukę w miejscowej szkole. Mieściła się w centrum wsi w zmodernizowanym budynku starej karczmy z 1902 r., miała dwie sale lekcyjne ze starymi ławkami uczniowskimi. Nad wejściem do niej widniał szyld z lat międzywojennych informujący, że to "Szkoła Powszechna I stopnia”. Uczyły w niej dwie nauczycielki dochodzące z sąsiednich miejscowości. Nie było w niej biblioteki szkolnej. Brak było jakichkolwiek pomocy dydaktycznych. Gdzieś na poddaszu Pani Kierowniczka (wspomniana J.J.) przechowywała kronikę szkolną z niestarannie wyszarpaną pierwszą kartką. Podobno wyrwał ją jeden ze stacjonujących w szkole w pierwszych dniach po przejściu frontu żołnierzy rosyjskich na tytoniowego „skręta”. Ponieważ wyrwana kartka była twarda i na „skręta” się nie nadawała, inni „czerwonoarmiejcy" zrezygnowali z dalszego niszczenia kroniki. Oczywiście szkoła pracowała w systemie klas łączonych (po latach, w czasie studiów, na zajęciach z dydaktyki byłem jedynym, który szybko pojął, na czym polegało nauczanie w klasach łączonych). Rosłem wraz z jej rozwojem organizacyjnym i kadrowym, dostrzegając wielką troskę i zapobiegliwość nauczycieli o jej rozwój. Byłem pierwszym rocznikiem, który w szkole tej tworzył klasę piątą, później szóstą, a następnie siódmą (dopiero w tej klasie, po przyjściu czwartego nauczyciela, doświadczyłem komfortu nauki rozłącznej). Przeżyłem wzruszające chwile związane $z$ jej rozwojem, jak wygospodarowanie dwu dodatkowych sal lekcyjnych w zdewastowanym (przez „państwowego” użytkownika) dworze zabranym bratu mojego dziadka, czy też przywiezienie (na rowerze), przez wspomnianego „Siwulę” uczącego geografii, pierwszych atlasów E. Romera z księgarni w Nowym Sączu (1949). Pamiętam, że przynosiliśmy z domu po 4 złote na te atlasy. Jeden z kolegów nie wpłacił tej sumy, bo ojciec odmówił dania pieniędzy. „Siwula” mieszkający w Nowym Sączu, nieopodal pospolitej restauracji często odwiedzanej przez miejscowych ko- 
lejarzy, „wyczaił” ojca wspomnianego kolegi wchodzącego z „kumplami” do tej restauracji. Wszedł tam i w przemyślny sposób, w stosownym momencie, dosiadł się do interesującego go ojca. Poinformował go o organizowanej akcji zakupu atlasów i o tym, że jego syn jeszcze się do tej akcji nie włączył. Skruszony ojciec stosowną sumę przekazał, wpisując się na podsuniętą mu listę wpłacających. W kilka dni później w klasie szkolnej jego synowi „Siwula” wręczył jako pierwszemu atlas ze specjalną pochwałą dla ojca za decyzję, jaką ten podjął. Tacy to byli - przynajmniej niektórzy - nauczyciele z czasów mojego dzieciństwa. Prawdopodobnie ich postawa, a może i częściowo sugestia wspomnianego „Siwuli”, z którym na stałe zaprzyjaźnił się mój ojciec, spowodowała, że jako miejsce dalszej nauki wybrałem liceum pedagogiczne.

\section{Szkoła niemal przeklęta}

Szanowna Pani Profesor, niestety źle wspominam wybraną mi szkolę średnią (nauczycielka J. J. sugerowała mi wybór liceum ogólnokształcącego). Przed laty, w okolicznościach, których nie chcę wspominać, stanąłem wobec konieczności wypowiedzenia się na temat rzeczy świętych i przeklętych. Ten drugi termin nasunął mi na myśl - wbrew zwyczajowi wygłaszania tradycyjnych pochwal i odwoływania się do dobrotliwego humoru - moją szkołę średnią. Mieściła się blisko centrum miasta przy Starym Cmentarzu w tzw. "Ciuciubabce”. Po latach dowiedziałem się, że ten piękny secesyjny budynek został zaprojektowany przez sądeckiego architekta Zenona A. Remiego, a wzniesiony w 1905 r. (prace murarskie) przez firmę budowlaną Konstantego Chrystiana Aleksandra (rodzonego brata mojego pradziadka). Konstanty Krystian Aleksander ukończył w Krakowie na UJ studia farmaceutyczne (1887 r.) z zamiarem założenia apteki w Nowym Sączu. Z powodu - jak przekazuje ustna tradycja - „żydowskiej konkurencji” nie uzyskał koncesji na aptekę. Założył drogerię, a później bank mieszczański, w którym pełnił funkcję prezesa. $Z$ początkiem XX w. założył firmę budowlaną i przy jej pomocy wzniósł kilka stylowych obiektów. Wchodziłem wiec codziennie do budynku nie wiedząc, kto go wybudował.

Do szkoły (już jako niespełna 14-latek) chodziłem ponad 5 kilometrów w jedną stronę - większość drogami gruntowymi i błotnistymi, a dopiero ostatni kilometr (ulice Nowego Sącza) chodnikiem. By sobie z tą drogą poradzić, w II klasie szkoły zakupiliśmy z ojcem „na tandecie” rozmaite stare części do roweru i złożyliśmy z nich zupełnie sprawny rower (zdobycie talonu na zakup nowego roweru nie było wtedy w moich warunkach możliwe), 
który ułatwił mi dostawanie się do szkoły. Szybko nauczyłem się jeździć po wyboistych i błotnistych drogach, miedzach i różnego typu drogowych przeszkodach. Stale jednak byłem łapany przez milicję za brak karty rowerowej. Nie mogłem jej otrzymać, bo w miejscu wyrabiania kart nie byłem w stanie okazać dokumentu zakupu roweru. Nauczyłem się jeździć bocznicami, gdzie szansa natrafienia na kontrolujących była mniejsza. Nie polubiłem tej szkoły z tego powodu, że po wielu lekcjach uczniowie obciążani byli sporą ilością zajęć dodatkowych: apele („prasówki”) przed lekcjami, wiece i uroczystości polityczne w mieście, których publiczność „powiększali” uczniowie, obowiązkowe biegi wiosenne i jesienne, rozmaite dodatkowe szkolenia ideologiczne po lekcjach i in. Wydłużały one pobyt uczniów, z reguły zmęczonych lekcjami, a niejednokrotnie i głodnych, na organizowanych im zajęciach, przynosząc niewielkie korzyści.

Była to szkoła bez tradycji, z dość pospiesznie dobraną kadrą nauczycielską. Znaczna jej część szczyciła się ukończeniem jedynie tzw. Wyższego Kursu Nauczycielskiego (WKN), co w sposób tragiczny wpływało na to, w jaki sposób przekazywali uczniom swoją wiedzę i czego od nich - jeśli idzie o przygotowanie - wymagali. W dodatku nie do zaakceptowania były u nich przypadki niekonsekwencji. Dam Pani Profesor przykład. Geografii uczył mnie S.G. Był to niesamowity pedant, jeśli idzie o strój. Podobno zostało mu to po wojsku, w którym wcześniej pracował jako podoficer. Mieszkał w szkolnym internacie żeńskim w odległości około 100 m od szkoły, do której docierał chodnikiem nawet nie przechodząc na drugą stronę jezdni. Dysponował dość dobrze wyposażoną (jedyną w szkole) pracownią geograficzną. Podejrzewam, że miał obsesje na temat znajomości Niecki Nidziańskiej i pasm górskich w Sudetach. Na jednej z lekcji zadał nam - jako zadanie domowe - narysowanie pasm górskich w Sudetach. Znalazłem w domu starą mapę tych gór, nałożyłem na nią arkusz białego papieru kancelaryjnego i odrysowałem 15 pasm górskich uważnie je następnie opisując: Góry Sowie, Góry Izerskie, Karkonosze, Góry Stołowe, Góry Wałbrzyskie itd. Na lekcji profesor G.S. z wściekłością poniszczył większości uczniowskich rysunków gór „przejeżdżając” po nich ostrym i długim paznokciem u małego palca prawej ręki. Moją mapę - po chwilowym namyśle - uznał za poprawnie wykonaną. Na koniec zadał to samo zadanie ponownie. Sprawdzając je znów przynajmniej połowie kolegów uszkodził wykonane mapy tym samym paznokciem. W mojej też coś go zafrapowało, ale nie stwierdził nieprawidłowości. Zadanie zadał trzeci raz informując, że za tydzień za mapy będzie wpisywał oceny. Jakiż przeżyłem szok, gdy w czasie ostatniego przeglądu map byłem jedynym w klasie, który otrzymał ocenę niedostateczną. Stałe 
zastraszenie spowodowało, że nigdy nie odważyłem się zapytać, z jakiego powodu tak się stało.

Albo inny przykład szkolnego „podpadnięcia”. Gdy byłem prawdopodobnie w II klasie oznajmiono nam, że po lekcjach mamy zostać na dodatkowy wykład zaproszonego prelegenta. Jako dyżurnemu polecono mi przynieść mapę Europy z pracowni geograficznej. „Będzie potrzebna do wykładu" - oznajmił polecający. Nie wiedziałem, że od dwu lat w Polsce działa Towarzystwo Wiedzy Powszechnej, którego celem jest min. popularyzacja wiedzy wśród dorosłych przez cykle odczytów. Takie odczyty zlokalizowane zostały w naszym Liceum, a przygotowywana przeze mnie sala miała służyć takiemu odczytowi. Wywiesiłem mapę na stojącym trójnogim stelażu z drewna, na zwyczajowo ustalonej wysokości. Nagle któryś z profesorów wprowadził do sali chłopinę zaskakująco niskiego wzrostu, który nie spoglądając nawet na zgromadzoną uczniowską widownię, wydobył z teczki broszurę i zaczął z niej czytać o amerykańskim „impraliźmie” i europejskich „podżegaczach” wojennych. Czytanie przerywał pokazywaniem krajów bałkańskich na mapie, która była dla niego zawieszona zbyt wysoko. Speszony sytuacją, jako dyżurny, dwukrotnie tę mapę obniżałem. Okazało się, że nawet zawieszona na najniższym możliwym poziomie, i tak była dla odwracającego się do niej prelegenta za wysoko. Przejęty i speszony sytuacją nic z odczytu nie zapamiętałem poza tym, że w Ameryce jest żarłoczny „impralizm”, a w Europie żyje największy „podżegacz” wojenny, jakim jest Josip Broz Tito. Na pewno odczyt był za trudny dla 16-letniego ucznia nie znającego się na polityce i „porażonego” podczas słuchania z powodu kłopotliwej sytuacji. Po latach, gdy jako samodzielny pracownik naukowy rozpocząłem współprace z TWP i miałem wgląd w sprawozdania z podatków akcji odczytowej Towarzystwa, uświadomiłem sobie źródło wysokiej statystycznie frekwencji słuchaczy na odczytach.

Tak się złożyło, że po miesiącu znów w naszej klasie podano informacje o kolejnym odczycie a mnie zobowiązano do ponownego przygotowania mapy. W nadziei, że na odczyt przyjdzie ten sam co poprzednio prelegent, mapę powiesiłem najniżej jak się dało, tak nisko, że jej dolna cześć sięgnęła podłogi. Tymczasem do sali wszedł, jako prelegent, dyrektor szkoły. Był mężczyzną szczupłym, wysokiego wzrostu. Spojrzał ze zdziwieniem na mapę i zapytał ostro: „Kto to zrobił?”. Byłem przekonany, że z tego „podpadnięcia" nigdy nie wyjdę.

Nie będę Pani mówił o innych rzeczach, wręcz obrzydliwych, wyjątkowo uczniów upokarzających, bo mi jest po prostu wstyd. Sam tego doświadczałem i dlatego szkołę tę źle wspominam. Po latach zastanawiam się - i to 
łagodzi moje oburzenie - czy nie stałem się w niej ofiarą zmowy nauczycieli za moje "pochodzenie" i noszone „nazwisko”, a być może wojenne winy kraju, skąd to nazwisko pochodzi.

\section{Na studiach odżyłem}

Pierwszy raz zobaczyłem Kraków w ostatniej klasie szkoły średniej, gdy z klasą szkolną wracaliśmy z jesiennego pobytu w Przesiece koło Jeleniej Góry. Przyjechaliśmy na Dworzec Główny i trzeba nam było oczekiwać dwie godziny na pociąg do Nowego Sącza. Motywowany wielkim zaciekawieniem miastem, znanym mi z opowiadań członków rodziny i lekcji historii, wymknąłem się opiekunowi i omijając sprytnie bramki, na których stali kontrolerzy biletowi, w pośpiechu przemknąłem za ludźmi Plantami do Bramy Floriańskiej, a następnie ulicą Floriańską do Rynku. Wpadłem na krótko do Kościoła Mariackiego (nie wiedząc, że to Mariacki), gdzie uległem pełnemu zauroczeniu jego wielkością i pięknem, alei zdziwieniu, że do jego wnętrza z płyty Rynku schodzi się w dół. Z tymi doznaniami szybko wróciłem do klasy na dworzec i zorientowałem się, że nikt nie zauważył mojego zniknięcia. Po latach, już jako pracownik naukowy, wybrałem się na odczyt do krakowskiego Oddziału PAN, na którym historycy sztuki omawiali przyczynę intrygującego mnie zjawiska.

Legalnie przyjechałem do Krakowa 1 lipca 1957 r. na egzamin wstępny na studia. Miałem dotrzeć do „Żaczka” na nocleg. Zatrzymany przechodzień poinformował mnie, że dojadę tam „zerówką" (tramwajem linii nr „0”). Nadjechał tramwaj, wsiadłem i poinformowałem (okazując zaproszenie na egzamin) radosną, sympatyczną konduktorkę o celu mojej podróży. Sprzedała mi bilet za jedyne 20 groszy i coś sympatycznie oznajmiła (nie słyszałem tego wyraźnie, bo koła skręcającego tramwaju głośno zgrzytnęły o szyny). Po pewnym czasie tramwaj się zatrzymał, konduktorka wyszła z kabiny motorniczego, podeszła do mnie, pokazała na lewo, na neogotycki ceglany budynek (Collegium Novum), i powiedziała: „Tutaj jutro pan przyjdzie na egzamin, dom studencki „Żaczek” pokażę panu dalej”. Po dwu następnych przystankach poleciła mi wysiąść wskazując, tym razem z prawej strony, duży jasny budynek, który zaskoczył mnie w równym stopniu wielkością, co i dużą ilością i gęstością okien. Po kilkunastu minutach znalazłem się $\mathrm{w}$ jednym $\mathrm{z}$ jego pokoi z trzema innymi rówieśnikami przybyłymi również na egzamin. Do tego budynku otrzymałem również przydział na mieszkanie (i korzystanie ze stołówki) po przyjęciu na studia. 
$\mathrm{Na}$ studiach, a studiowałem pedagogikę $\mathrm{z}$ przedmiotem pobocznym historia (na którym wykładali ci sami profesorowie co na kierunku historia), zaraz na początku zaskoczyło mnie to, że trafiłem na profesorów o postawie normalnych ludzi. Byli wśród nich wspaniali uczeni jak: Kazimierz Piwarski - wybitny historyk, ostatni w UJ sekretarz akcji Wykładów Powszechnych, Jan Zborowski - doskonały dydaktyk, Stefan Szuman psycholog rozwoju, Danuta Gierulanka - matematyk i specjalista z psychologii doświadczalnej, Jan Konopnicki - innowacyjny metodolog i oryginalny badacz niedostosowania społecznego (pierwszy dyrektor Instytutu Pedagogiki), Henryk Barycz - niedościgniony znawca dziejów kultury, Jan Hulewicz - wybitny popularyzator wiedzy o dziejach szkolnictwa (promotor mojej pracy magisterskiej), Kamila Mrozowska - specjalistka od historii oświaty i szkolnictwa, Tadeusz Słowikowski - metodyk nauczania, no i oczywiście Maksymilian Siemieński - teoretyk oświaty dorosłych. Ich uporządkowane, treściwe i piękną polszczyzną wygłaszane wykłady były (w porównaniu do tego, czego doświadczyłem w szkole średniej) czymś wspaniałym. $Z$ tonu wykładu czuło się ich życzliwość wobec studentów i troskę o jak najlepsze przekazanie im wiedzy. W indywidualnej rozmowie ze studentami byli normalnymi ludźmi, czasem taktownie pytali o warunki bytu i miejsce pochodzenia, o posiadane książki (niejednokrotnie w przypadku ich niedostępności oferowali pozycje $z$ własnych księgozbiorów) i pomoce do studiowania, a także o możliwości indywidualnej nauki studenta. Żaden z nich nie śmiał się z dostrzeżonej nieporadności studenckiej, nie karcił za niewiedzę. Wręcz przeciwnie - widziało się wich oczach radość z postępów rozwoju studentów, co też w rozmowach indywidualnych ze studentami oznajmiali motywując tym do dalszej nauki. Widać u nich było troskę o studenta i jego rozwój. Pozwolę sobie podać przykład potwierdzający tę postawę. Byłem na III roku studiów. Pewnego dnia zamyślony przechodziłem przez - jak zwykle ludny - Rynek krakowski. Ktoś nagle pociągnął mnie za rękaw - odwracam głowę w bok, a to profesor Jan Hulewicz. Zatrzymałem się niezwykle zaskoczony, a Profesor, wciskając mi w dłoń kilka cukierków, mówi: „Wie pan, poszukuję w Bibliotece Jagiellońskiej informacji, by panu dokładniej odpowiedzieć na zadane mi pytanie na ostatnim wykładzie. Jeszcze nie znalazłem. Niech pan jeszcze zaczeka”. Po kilku dniach otrzymałem taką odpowiedź, a dotyczyła ona sposobu dostarczania książek w dobie Komisji Edukacji Narodowej do szkół średnich na terenach dzisiejszej Ukrainy.

Odrębne uznanie należy wyrazić bibliotekom uniwersyteckim, instytutowej i uczelnianej tj. Bibliotece Jagiellońskiej. Spędziłem w nich - zwłaszcza w Bibliotece Jagiellońskiej - połowę życia studenckiego i nadal spędzam 
w niej wiele czasu. Bez pracy w niej nie ma studiów i prawdziwej metody naukowej. W niej widać, czym jest i czym powinien być bibliotekarz jako doradca i pomocnik studenta, a także pracownika naukowego. Nie dziwię się, że profesor Jan Hulewicz - opiekun mojej pracy magisterskiej i recenzent z habilitacji -zawsze, co często obserwowałem, wędrował po salach mieszczących poszczególne katalogi w poszukiwaniu książek z najbardziej doświadczonymi kustoszami w tej bibliotece. Dostąpiłem i ja czegoś niezwykłego w tej instytucji świadczącego o bardzo wysokiej kulturze organizacyjnej i wspaniałomyślności pracowników. W swojej młodości - już asystenckiej - poszukiwałem jakiejś książki. Po wysłaniu rewersu otrzymałem jego zwrot informujący, że książki w magazynie nie odnaleziono. Pracownica wypożyczalni sprawdziła, że jest jeszcze egzemplarz archiwalny, ale ten można wypożyczyć do czytelni jedynie za osobistą zgodą dyrektora. Wypełniłem więc rewers i udałem się z nim do gabinetu dyrektora, w którym w czasie mojej wizyty wykonywał swoje obowiązki wicedyrektor profesor Karol Lewicki. Przedstawiłem się i sformułowałem swoją prośbę o zgodę na udostępnienie wspomnianego egzemplarza archiwalnego. Profesor zachęcił mnie, bym usiadł naprzeciw niego, zaś on pochylony nad rewersem zaczął wypisywać na nim swoją zgodę. Wtedy dostrzegłem w całości piękną, sporej wielkości panoramę jakiegoś urokliwego, a nieznanego mi miasta wiszącą za jego plecami. Natychmiast go przeprosiłem i niemal odruchowo zapytałem, co to za miasto. Profesor podniósł głowę, dobrotliwie ze spokojem spojrzał na mnie i pyta: „pan nie był nigdy we Lwowie?”. „Nie byłem - odpowiedziałem - ale mój ojciec był tam w czasie «uciekinierki»". Wywiązała się między nami długa rozmowa, w czasie której od Profesora - rodowitego lwowianina - dowiedziałem się dużo o tym mieście, znanym mi jedynie z literatury i skromnych relacji ojca. Pożegnaliśmy się i wyszedłem. Po około 15 minutach wszedłem do Instytutu, a na klatce schodowej stała pani Dyrektor - prof. Kamila Mrozowska, i pyta: „Tadeusz, co ty masz wspólnego z Profesorem Karolem Lewickim, bo on tu za tobą dzwoni z informacją, że książka się odnalazła”. Pani Profesor, taki był Uniwersytet mojej młodości, bo ludzie o wysokiej kulturze akademickiej go stanowili! Co zaś do Biblioteki Jagiellońskiej, to przyznać trzeba, że zasłużyła na to, by uznać ją za prawdziwy mózg uniwersytetu.

\section{Klęski nie poniosłem}

Szczęściło mi się również po studiach. W kilka dni po zdaniu egzaminu magisterskiego, w czerwcu 1962 r. wybrałem się w celu znalezienia pracy do 
Katowic. Dzięki życzliwej poradzie i wyraźnej pomocy (list polecający) profesora Jana Zborowskiego, dotarłem do kierownika działu kształcenia nauczycieli Kuratorium Śląskiego. Ten, po wyjątkowo sympatycznej rozmowie, obiecał mi zatrudnienie na stanowisku nauczyciela przedmiotów pedagogicznych w Studium Nauczycielskim w Cieszynie. Po załatwieniu formalności związanych z zatrudnieniem jeszcze w lipcu wybrałem się do Cieszyna. W Studium przyjął mnie dyrektor Antoni Zając, mężczyzna średniego wzrostu, bardzo operatywny, zajmujący się intensywnie, oprócz pracy w SN, badaniami dziejów oświaty na Śląsku Cieszyńskim (z tego zakresu nieco później napisał rozprawę doktorską). Przyjazna rozmowa sprawiła, że od razu nabrałem zaufania do niego jako mojego zwierzchnika. Wnet po tym zjawiłem się w Cieszynie z dużym „posagiem”, jakim były bruliony z notatkami po prawie wszystkich wykładach w czasie studiów oraz wypisy z przeczytanej wtedy lektury (nie tylko do egzaminów). Zamieszkałem w jednej z cieszyńskich kamienic, w pokoju (bez wody) „załatwionym” mi przez prezesa tamtejszego Oddziału ZNP. Cieszyn, jako miasto, zrobił na mnie dobre wrażenie: miasta ładnie zabudowanego, ludnego (szczególnie w porze przed rozpoczęciem i zakończeniem pracy w miejscowych zakładach), o sporym ruchu samochodowym na ulicach, stąd brukowana nawierzchnia tych ulic wydawała mi się znacznie bardziej „wyjeżdżona” niż w miastach Małopolski, a i sklepy wszystkich branż wydawały mi się lepiej zaopatrzone w towary niż w Nowym Sączu czy nawet Krakowie. Oprócz wyglądu miasta zauroczyła mnie cieszyńska gwara, którą posługiwali się na co dzień nawet ludzie wykształceni (jeśli byli sami, bo gdy tylko pojawił się miedzy nimi człowiek „nie stela”, przechodzili na język literacki polski). Zachwyt pięknem tej gwary bawił jak mi się wtedy wydawało - moją sąsiadkę, starszą panią, imienniczkę i rówieśnicę mojej matki, żonę Zaolzianina Raszki, kierowcy wcielonego podczas wojny do Wermachtu. Nic też dziwnego, że często prowokacyjnie ze mną rozmawiała używając z pasją takich słów jak: „paryzol” - parasol. „cera”córka, „porcynkula” - odpust w parafii, „młoducha” - panna młoda i in.

Studium Nauczycielskie, w którym pracowałem, zlokalizowany było $\mathrm{w}$ okazałym, starannie odnowionym (przez prywatną firmę remontową z Bielska) budynku dawnego Liceum Pedagogicznego, po którym przejęło dużą bibliotekę z czytelnią i kilka pracowni przedmiotowych (w tym muzyczną). Szkoła miała także wygodny internat dla słuchaczy. Nauczali w niej doskonali nauczyciele: dawni wykładowcy miejscowej Wyższej Szkoły Gospodarstwa Wiejskiego, którzy ze względów rodzinnych nie przenieśli się z nią do Olsztyna. Uczyli w nim także byli nauczyciele i dyrektorzy w zasadzie jeszcze likwidowanego Liceum Pedagogicznego. Większość z nich pro- 
wadziła rozmaite badania naukowe, najmłodsi przygotowywali rozprawy doktorskie.

Warto przypomnieć też, że w budynku tym kiedyś nauczał (Seminarium Nauczycielskie) Józef Pieter, a po II wojnie światowej także Stanisław Hadyna (w Cieszynie zwerbował kilka pierwszych śpiewaczek do tworzonego Zespołu Pieśni i Tańca "Śląsk”). Prawdopodobnie z tego powodu spacerując po obszernych korytarzach tego budynku odnosiłem wrażenie, że tutaj „czuć” psychologią, a w salach słychać śpiew. W SN, prawdopodobnie ze względu na miejscowe tradycje i możliwości kadrowe, były dwa kierunki kształcenia: rolnictwo - przygotowujące nauczycieli zawodu do zasadniczych szkół rolniczych oraz szkół przysposobienia rolniczego, oraz wychowanie muzyczne - przygotowujące nauczycieli śpiewu do szkół podstawowych i instytucji zajęć pozaszkolnych. Słuchacze (niektórzy przyszli do SN po kilku latach przerwy w nauce od czasu matury) byli na ogół bardzo pracowici i zainteresowani nauką. Pochodzili z całego niemal Śląska, co spowodowane było niewielką jeszcze liczbą szkół pomaturalnych w innych częściach tego regionu, najczęściej z rodzin górników i hutników, pracowników firm remontowych i budowlanych, przedsiębiorstw komunikacyjnych, a także nauczycielskich. Następstwem tego pochodzenia i chęci otrzymania „lepszej" (niż zajęcie rodziców) pracy były w dużej mierze źródłem ich, godnego podkreślenia, zapału do nauki.

Do zajęć z tymi słuchaczami starałem się starannie przygotować. Stąd długo siedziałem nad wspomnianymi notatkami z uniwersytetu, książkami przywiezionymi z sobą oraz wypożyczonymi z biblioteki Studium. Po latach stwierdzam, że, z powodu konieczności przygotowania się do zajęć, czas ten był dla mnie okresem intensywniejszej nauki niż na studiach. Ponieważ nie wszystkie potrzebne książki mogłem wypożyczyć do domu, wiele godzin spędzałem nad nimi w czytelni bibliotecznej. Zaistniały tam przypadkowy incydent przyczynił się bardzo znacząco, a niemal niespodziewanie, do mojej nobilitacji jako nauczyciela. Pewnego razu do biblioteki zakupiona została nowa i potrzebna Mała encyklopedia PWN. Czytając w niej hasło „Dawid Jan Władysław" dostrzegłem błąd w dacie śmierci tego psychologa (autorzy encyklopedii podali rok, po którym Dawid żył jeszcze w dobrym zdrowiu trzy lata). Podszedłem do dyżurującej bibliotekarki i pokazuję błąd z uwagą o zaniedbaniu korekty przez redaktora encyklopedii i z sugestią, czy nie powinna tego błędu w tekście poprawić. Wracając na swoje miejsce zauważyłem, że w czytelni jest wielu słuchaczy a niektórzy jakoś dziwnie spoglądają na mnie. 
Pani Profesor, nie wiem czy dobry, czy zły duch sprawił, że dwa dni po opisanym incydencie zjawiłem się znów w wymienionej czytelni i sięgnąłem ponownie do tej samej encyklopedii (któregoś dnia była do nabycia w cieszyńskiej księgarni naukowej, ale nie kupiłem, bo cena jej równała się jednej piątej moich miesięcznych poborów potrzebnych mi na "pilniejsze” wydatki). Przeglądam ją uważnie, by zorientować się w ilości i treści różnych haseł, patrzę, a tu kolejny błąd, tym razem w pisowni nazwy „Chiny” (przez samo „H”). Entuzjastycznie powtórzyłem reakcje sprzed dwu dni - jak się okazało i tym razem przy „świadkach”. Od tego momentu nawet oporni wobec nauki słuchacze spoglądali na mnie przyjaźniej i - jak mi się wydaje - wykazywali większe zaufanie do treści przekazywanych przeze mnie na zajęciach.

Dzięki namowie kolegów nauczycieli zacząłem też uczęszczać na zebrania nauczycielskie oraz różne formy dokształcania (odczyty, spotkania z twórcami, dyskusje z kierownikami miejscowych instytucji oświaty i kultury) przedstawicieli tego zawodu. Z czasem „pociągnęły” mnie też zebrania („otwarte”) organizacji gospodarczych i stronnictw politycznych, a to ze względu na interesujące referaty i fascynujące niekiedy dyskusje. Dostrzegłem, że każde takie zebranie kończyło się patriotycznym wnioskiem o konieczności powrotu Zaolzia do Polski. Nawet gdy na jakieś zebranie do Cieszyna przyjechał wicewojewoda śląski i po wygłoszeniu bardzo konstruktywnego referatu na temat kierunków rozwoju gospodarczego kraju i Śląska zainicjował dyskusję, usłyszał jako pierwsze pytanie: „Panie wojewodo, kiedy Zaolzie z powrotem do nas przyłączycie”. Ta ogólna tęsknota do Zaolzia spowodowała, że i ja postanowiłem je przynajmniej częściowo poznać. Pod pretekstem poszukiwania materiałów do dziejów przemysłu w czeskim Cieszynie otrzymałem przepustkę upoważniającą do wielokrotnego przekraczania granicy. Kwerenda archiwalna, jak i wędrówki turystyczne, a zwłaszcza poznawanie polskich instytucji kultury i oświaty, spowodowały, że zrodził się u mnie pomysł na doktorat na temat ruchu oświatowego na Ziemi Cieszyńskiej w dobie autonomicznej. Do realizacji tego pomysłu się jednak nie zabrałem z powodu pojawienia się nowych możliwości, jeśli idzie o miejsce i rodzaj pracy.

W szkołach na terenie Cieszyna i powiatu cieszyńskiego była od dawna dobrze rozwinięta tzw. pedagogizacja rodziców. Dyrektor Studium namawiał mnie bym w jej ramach czasem udał się na wykład dla rodziców w szkole, początkowo za niego, a później na „własny rachunek”. Tak zacząłem jeździć po górskich wioskach Ziemi Cieszyńskiej z wykładami o treści psychologiczno-pedagogicznej. Do każdego wykładu długo się przygotowywałem, czytając najnowszą literaturę z potrzebnego mi zakresu. Zauważy- 
łem, że te wykłady nawet się ludziom podobają. Po wykładzie zadawali pytania, a nawet dyskutowali. Klęski w tym zakresie nie poniosłem.

\section{Ponownie uniwersytet}

W takich okolicznościach zawodowych i środowiskowych otrzymałem wiosną 1964 r. list od profesora Maksymiliana Siemińskiego. Profesor informował w nim, że otrzymał etat asystencki w swojej Katedrze i że proponuje mi przejście do pracy w UJ. Bardzo ostrożnie zaznaczył też, iż wydaje mu się, że do tej pracy się nadaję. Niewiele się zastanawiając, z dniem 1 października, rozpocząłem pracę w Katedrze Oświaty i Kultury Dorosłych jako asystent, gdzie pracowałem nieprzerwanie do 31 sierpnia 2009 roku tj. dokładnie 45 lat, przechodząc kolejno wszystkie etapy rozwoju naukowego i pokonując przy tym ogromne przeszkody (długie oczekiwanie na recenzje prac, realizacja w obiektywnie trudnych warunkach badań, godzenie dużej liczby niełatwych do realizacji zajęć dydaktycznych z niewielką ilością czasu na pracę naukową, poszukiwanie finansów na opublikowanie z trudem napisanych rozpraw i in.) Odtworzenie dzisiaj tej naukowej Golgoty wymagałoby napisania opasłej książki, czego - z różnych powodów - już się nie podejmę.

Profesor M. Siemieński (jak na Mistrza przystało dużo ze mną rozmawiał na tematy naukowe i dydaktyczne), wiedząc skąd pochodzę zasugerował mi, zaraz na początku pracy, temat rozprawy doktorskiej. Treścią jej miało być ukazanie drogi oświatowej (nauka w szkole średniej i wyższej) młodzieży wiejskiej, a chłopskiej w szczególności. Jako teren badań wybrałem znaną mi Ziemię Sądecką. Jeździłem wtedy (a właściwie z braku komunikacji więcej chodziłem) po wybranych wsiach i początkowo przy pomocy miejscowych nauczycieli i innych ludzi światłych, a także dokumentacji szkolnej $z$ lat minionych wypisywałem nazwiska i imiona oraz ustalałem miejsce pobytu osób, które po ukończeniu miejscowej szkoły podstawowej poszli się dalej uczyć. Następnie bezpośrednio, w miarę możliwości czasowych i finansowych, docierałem do tych ludzi robiąc wywiad na temat ich drogi oświatowej (motywów, kierunków i warunków kształcenia). Tym, do których nie dotarłem bezpośrednio, wysyłałem ankietę. Zaskoczyło mnie, że otrzymałem prawie 100 procent zwrotu wysłanych ankiet, na ogół bardzo starannie wypełnionych. W czasie wędrówek po wsiach sporo się nauczyłem. Zaskakiwało mnie $z$ jednej strony duże jeszcze zaniedbanie cywilizacyjne odwiedzanych wsi (zwłaszcza połemkowskich), z drugiej - wielki zapał ludzi do działań na rzecz poprawy tej sytuacji wyrażony w postaci budowy (w tzw. 
czynie społecznym) dróg, elektryfikacji, wznoszenia i remontowania budynków szkolnych oraz in. Pracowała w tym kierunku niekiedy cała wieś. W Bukowcu niedaleko Grybowa budową drogi kierował ksiądz Bocheński, miejscowy proboszcz, przewożąc także własnym koniem pozyskany przez siebie tłuczeń. Nade wszystko uderzył mnie podczas tych badań wielki zapał młodzieży chłopskiej do nauki jako sposobu na poprawienie swojego losu, zaś u już wykształconych troska o wieś swego pochodzenia. W wyniku tych badań napisałem pracę doktorską (po zmarłym w grudniu 1966 r. profesorze M. Siemieńskim promotorem jej został profesor Jan Konopnicki, recenzentami profesorowie: Kamila Mrozowska i Tadeusz Nowacki). Pracę wydałem nadając jej tytuł Awans oświatowy młodzieży wiejskiej (LSW, 1968). Ktoś tę rozprawę dostrzegł i dostałem za nią drugą nagrodę w ogólnopolskim konkursie na pracę naukową o wsi (nagrodą pierwszą wyróżniono książkę z zakresu polityki rolnej).

Po napisaniu doktoratu zostało mi dużo niewykorzystanego materiału. Traktował on o przemianach społecznych i życiu kulturalnym mieszkańców wsi. Zainteresowała się tym życzliwa mi dyrektor Instytutu Pedagogiki, powstałego w 1968 r. z połączenia Katedry Pedagogiki i Kultury Oświaty i Kultury Dorosłych, doradziła mi, jak go przez kolejne badania powiększyć, i poleciła pisanie następnej książki. Tak powstały Uwarunkowania uczestnictwa kulturalnego ludności wiejskiej (PWN, 1974). W oparciu o tę pozycję udało mi się w roku 1975 zrobić habilitację.

Po uzyskaniu stopnia doktora habilitowanego kontynuowałem nadal różne badania. Główny swój wysiłek uniwersytecki musiałem skierować na dydaktykę. Mieliśmy w Instytucie blisko 1300 studentów (trzy kierunki studiów) na studiach stacjonarnych i zaocznych. Przez wiele lat nauczałem w semestrze po 9 różnych przedmiotów (większość bardzo źle osadzonych w literaturze naukowej), prowadziłem po 4 (dwa na studiach stacjonarnych i dwa na zaocznych) seminaria magisterskie po prawie 20 studentów na każdym. Do tego zajęcia z elementów nauk pedagogicznych na tzw. kierunkach nauczycielskich, poprawianie studenckich prac i recenzowanie różnych tekstów do druku, pobyt (głównie wieczorami) na wielogodzinnych zebraniach i konferencjach i to nie tylko w Uniwersytecie, ale i w instytucjach, z którymi „wypadało” współpracować. Jednym słowem - koszmar.

Tak zaabsorbowany, chyba jako ostatni z pracowników Instytutu, dostrzegłem, że coś się w nim „popsuło”. Dostrzegłem to, gdy zupełnie w nieuzasadniony sposób uczyniono mi jakąś sporą przykrość. Z Instytutu odeszli na emerytury dawni wspaniali profesorowie. Ich miejsce zajęli nowi ludzie, $\mathrm{w}$ niektórych przypadkach z pozauniwersyteckich środowisk (jeden - 
dawniej wyrotowany - z takiego środowiska powrócił). Nie znali uniwersyteckich zwyczajów i uświęconych tradycją akademicką procedur poprawnego załatwiania codziennych spraw. Podejmowali dość nieporadnie chybione decyzje, czyniąc przykrość pracownikom, a niejednokrotnie krzywdząc kolegów. Wskutek tego z Instytutu odeszło kilku kolegów, którzy następnie znacząco przyczynili się do naukowego rozwoju nowych miejsc pracy. Otrzymałem i ja dwie propozycje przeniesienia się do innych miejscowości. Nie odważyłem się na to z powodu choroby żony, której stan wymagał czasem dotarcia do dwu („stałych”) lekarzy w ciągu jednego dnia.

Znosząc więc dalej różne w Instytucie przykrości skierowałem wyraźnie swoją aktywność naukową „na zewnątrz”, na różne formy współpracy z innymi instytucjami naukowymi i oświatowymi, np. z TWP, gdzie przez lata byłem członkiem ogólnopolskiej Rady Naukowej tego stowarzyszenia a nawet jego wiceprezesem. Rozszerzyłem także zakres swojej pracy naukowej o interesujące mnie zagadnienia regionalne (książka: Życie społeczne i przemiany kulturalne Nowego Sqcza, w latach 1870-1990, Kraków 1993). Pasje regionalne tkwią we mnie do dzisiaj i czuję, że się z nich nie wyzwolę.

W 1994 r., po 19 latach po habilitacji otrzymałem od Pana Prezydenta RP Lecha Wałęsy nominację profesorską. Umocniony tym faktem odważniej zacząłem kierować Zakładem Pedagogiki Dorosłych. Miałem tam doskonały zespół młodych współpracowników. W stosunkowo krótkim czasie jego członkowie doszli do doktoratu, a dr Ewa Bobrowska prawie zakończyła habilitację. Opracowaliśmy kilka niezłych książek andragogicznych oraz zorganizowaliśmy kilka znaczących konferencji, w tym dwie z okazji 50-lecia (1996 r.) i 60-lecia (2006 r.) istnienia Zakładu. Nawiązując zaś do 80-lecia ogólnopolskiej konferencji pracowników oświatowych RP w Kazimierzu nad Wisłą (maj 1929 r.) i pierwszej Wszechświatowej Konferencji Kształcenia Dorosłych w Cambridge (sierpien 1929 r.) zorganizowaliśmy w murach Uniwersytetu Jagiellońskiego w czerwcu 2009 r. wspomniany I Ogólnopolski Zjazd Andragogiczny.

\section{Dydaktyka}

Jak Pani Profesor wie, zawsze miałem dużo zajęć dydaktycznych, lubiłem zajęcia dydaktyczne i zawsze $\mathrm{w}$ miarę możliwości starannie się do nich przygotowywałem. $Z$ tym, że jak na warunki uniwersyteckie miałem ich za dużo - w ciągu tygodnia na studiach stacjonarnych, a w piątek (po południu), sobotę i niedzielę (i to do późnych godzin) także na studiach za- 
ocznych. W moim Instytucie były przez lata trzy kierunki studiów (stacjonarnych i zaocznych): pedagogika kulturalno-oświatowa (od lat 90. XX w. animacja kultury), resocjalizacja oraz pedagogika opiekuńcza. Na każdym roku średnio po 70 słuchaczy. Nauczałem na tych studiach różnych przedmiotów (średnio - co powtarzam - 9 w semestrze). Najczęściej była to andragogika, teoria pracy kulturalno-oświatowej i metodyka różnych działań wychowawczych oraz profilaktyki niedostosowania społecznego. Formy zajęć to: wykłady, konwersatoria, ćwiczenia i oczywiście praktyki. By jakoś studentom te zajęcia uatrakcyjnić, uciekałem się do różnych metod ich realizacji. Bardzo w tym pomagał mi kontakt z praktyką i praktykami. Podam przykład. Przez wiele lat realizowałem na jednej ze specjalności „Zagadnienia dokształcania i doskonalenia zawodowego". W wyniku kilkuletnich prób miałem w przedsiębiorstwach gospodarczych Krakowa i okolicy zaprzyjaźnionych pracowników w działach szkolenia zawodowego. Do każdego z nich wybierałem się raz w roku, w umówiony dzień, po to, by zwiedzić istniejące tam stanowiska produkcyjne i zobaczyć pracę zatrudnionych na nich osób. Po tym rozmawialiśmy $\mathrm{z}$ fachowcami od spraw zatrudnienia $\mathrm{w}$ dziale kadr, by w końcu, spotkać się $\mathrm{w}$ dziale szkolenia $\mathrm{z}$ osobami organizującymi dokształcanie i doskonalenie zawodowe, a nawet uczestniczyć w jakiejś realizowanej wtedy formie podnoszenia poziomu kwalifikacji. Organizacja i realizacja tych zajęć wymagała ode mnie dużego wysiłku i pomysłowości, ale się opłacała. Tym sposobem wykształciłem kilkudziesięciu dobrych pedagogów pracy, którzy zatrudnieni na podobnych do omawianych stanowiskach w innych przedsiębiorstwach pomagali mi w edukacji swoich młodszych kolegów.

Uciążliwe były niekiedy i seminaria magisterskie, a to z powodu dużej liczby grup seminaryjnych i nadmiaru seminarzystów na większości z nich. Długo szukałem sposobu na usprawnienie i ułatwienie sobie tych zajęć. Znalazłem go w strategii łączenia studentów w 2-3 osobowe grupy wzajemnej pomocy (jeden drugiemu prace poprawiał i odwrotnie) W wielu przypadkach było to skuteczne.

Ważną i trudną część mojej uniwersyteckiej „dydaktyki” stanowiły zajęcia z pedagogiki dla studentów tzw. kierunków nauczycielskich: geografii, historii, fizyki, matematyki i in. Miały one na cel przysposobić słuchaczy tych studiów do przyszłej pracy w szkole. Mając za sobą liceum pedagogiczne, studia z pedagogiki ( $\mathrm{z}$ historią) w Uniwersytecie, a także praktykę nauczycielska w Cieszynie, jakoś sobie z tym - mimo dużej liczby słuchaczy - dawałem radę. Zauważyłem nawet, że dyrektor mojego Instytutu kieruje mnie na trudniejsze odcinki tej pracy. Do takich w pewnym okresie należała filo- 
logia polska. W jakimś okresie jej studenci nie chcieli słyszeć o żadnej pedagogice. Powszechnie aspirowali do tego, by być w przyszłości literatami, redaktorami w wydawnictwach, menedżerami w koncernach prasowych, radio i telewizji, a nie do tego, by zostać nauczycielami w szkole. Realia zawodowe natomiast były dla nich zupełnie inne. Obciążenie pracowników Instytutu tymi obowiązkami zanikło z chwilą reaktywowania w UJ Studium Pedagogicznego, edukującego ochotników do pracy nauczycielskiej w szkolnictwie.

Ale zostały nam jeszcze zajęcia z zakresu dydaktyki akademickiej dla doktorantów i stażystów prawie wszystkich uniwersyteckich wydziałów oraz Collegium Medicum. To też specyficzny rozdział w moich doświadczeniach dydaktycznych. Pewnego razu przyszedł na nie asystent kliniki chirurgicznej z odciskami na twarzy po zdjętej masce zasłaniającej jego twarz podczas zakończonej przed godziną operacji. Niełatwo było te zajęcia prowadzić z zabieganymi prawnikami. Oprócz „niepewnej” asystentury w swoich katedrach, większość z nich była na aplikacji (adwokackiej, sędziowskiej, prokuratorskiej, radcowskiej), gdzie wymagający zwierzchnicy stwarzali im szanse niezłej stałej pracy.

\section{Współczesna andragogika}

Droga Pani Profesor, pyta Pani o współczesną andragogikę. W próbie odpowiedzi na to pytanie sięgnę do koncepcji nauki w pewnym stopniu naszego krakowskiego nauczyciela - profesora Zygmunta Mysłakowskiego. Już przed laty uznał on, że nauka to dyscyplina umysłowa, która ma swój przedmiot, odrębne metody badań i własny język, czyli terminologię. Jeśli idzie o przedmiot to andragogikę należy dzisiaj traktować jako naukę o formach i metodach wspierania wszechstronnego (wielostronnego) rozwoju człowieka w okresie jego dorosłości. Wyraźnie wydzielić tu (umownie) trzeba dwa obszary tego wsparcia: dokształcanie i doskonalenie zawodowe realizowane za pomocą dużej już dzisiaj ilości oryginalnych form rozwoju pracowniczego. Niech Pani przypomni sobie, ilu ludzi co roku rozpoczyna u nas pracę na różnych stanowiskach (poza ewentualnie stanowiskami komputerowymi) niczego w zasadzie nie umiejąc. Trzeba ich wszystkiego w pracy nauczyć: zasad bezpieczeństwa pracy, poszanowania zasobów firmy, sprawnego i efektywnego wykonywania czynności zawodowych, poprawnego zachowania się wobec innych pracowników i opanowania zasad współpracy z nimi. Obszar drugi to wsparcie rozwoju człowieka w jego czasie wolnym przeznaczonym na wypoczynek, zajęcia hobbistyczne i kulturę. Ten drugi obszar to rozmai- 
te formy bezinteresownego ogólnego kształcenia i rozwoju ludzi dorosłych. Zmierzać one winny do kształtowania rozumności w postępowaniu wobec ludzi, kraju i społeczności międzynarodowej, ukształtowania nawyków pracowitości i staranności, a także rozległych pasji poznawczych. Ma to więc być wspieranie rozwoju, które przeciwstawi się indywidualnej i społecznej głupocie, pleniącemu się lenistwu umysłowemu, intelektualnemu niedbalstwu i minimalizmowi, zobojętnieniu moralnemu i prostackiemu zachowaniu. W przeszłości naszej praktyki wspierania rozwoju ogólnego znaleźć można takie formy ogólnokształcącej (niezawodowe) edukacji dorosłych - przykładem praktyka edukacyjno-wychowawcza uniwersytetów ludowych, wszechnic miejskich, ruchów abstynenckich i wolnościowych. Trzeba te dwa obszary wspierania rozwoju człowieka dorosłego pogodzić. Mówię o tym dlatego, że od lat obserwuję z jednej strony jakąś niechęć andragogów ogólnych do andragogów pracy, a z drugiej skłonność do izolacji pedagogiki pracy i zamykania się w zainteresowaniu tylko swoimi zagadnieniami. Znam dobrze powody tej sytuacji. Powinna się ona zmienić, bo zmiana taka doprowadzi do wzajemnego wzmocnienia i powstania nowych jakości edukacyjnych.

Część druga andragogiki jako dyscypliny naukowej to metodologia. Mamy dziś na ten temat sporą i starannie wyłożoną wiedzę. Przyczynił się do tego profesor Aleksander Kamiński pisząc syntetyzujący tekst na temat metodologii pedagogiki społecznej. A teoria oświaty dorosłych, czyli dzisiejsza andragogika, uznana została przez przedstawicieli naukowej szkoły, w której wyrósł Aleksander Kamiński, za część składową pedagogiki społecznej. Dużo dobrego w obszarze metodologii badań andragogicznych zrobiła profesor Olga Czerniawska proponując andragogom w badaniach oświatowych metodę biograficzną. To doskonała metoda. Techniką wywiadu z badanym i analizy jego dokumentów osobistych dotyczących kształcenia można doskonale poznać drogę oświatową każdego dorosłego tym bardziej, że większość dorosłych na ogół chętnie mówi o swojej edukacji i jej licznych uwarunkowaniach. Niepokoi mnie dzisiaj spora trudność w realizacji współczesnych badań. Pretekstem do niej stała się treść Ustawy z dnia 29 sierpnia 1997 r. o ochronie danych osobowych. „Zastawiając” się nią kierownicy różnych instytucji gospodarczych i usługowych często nie wyrażają zgody na przeprowadzenie nawet drobnych badań w swoich instytucjach, nie mówiąc już o tym, że złośliwi i leniwi kierownicy tych instytucji mogą pod pozorem zabezpieczania danych osobowych swoich pracowników zabronić wszelkich badań. Uskarżają mi się niejednokrotnie na taką postawę magistranci i doktoranci gromadzący materiały do swoich prac. Doświadczam tego i ja osobiście. W ubiegłym roku, przygotowując pracowicie 
monografię swojej rodziny, wybrałem się z Krakowa do Gdyni, by w jednej z tamtejszych firm z teczki osobowej (z 1962 r.) mojego pracującego tam, a zaginionego kuzyna dowiedzieć się czegoś o nim. Mimo usilnych starań teczki mi nie udostępniono, grożąc konsekwencjami wypływającymi z nieposzanowania ustaleń wymienionej Ustawy. Dzisiaj coraz częściej słyszę, że ustawa ta nie obowiązuje w przypadku badań naukowych, tak jak nie może być stosowaną w przypadku śledztwa. Byłoby dobrze, gdyby twórcy tej Ustawy wypowiedzieli się jasno na ten temat.

I jest trzeci element nauki. Jest to także wyznacznik jej naukowej dojrzałości. Pod tym względem $\mathrm{w}$ andragogice jest źle. Posługuje się ona często językiem potocznym i w związku z tym tezy swoje wypowiada w terminologii nieostrej i niejednoznacznej. Jedni mówią w niej, opisując to samo, o człowieku „dorosłym”, inni „dojrzałym”, a jeszcze inni - „pełnoletnim”. Szanowany profesor Antoni Gładysz przed laty żartował jeszcze o człowieku „wcześniej urodzonym”. Przed kilkoma miesiącami oceniałem prace z geragogiki, prawie popsutą tym, że autorka niekonsekwentnie tych samych ludzi na jednych stronach nazywała "starymi”, na innych „starszymi”, a jeszcze gdzie indziej „starzejącymi się”. Mój profesor Maksymilian Siemieński proponował, by zostać przy pojęciu „człowiek w wieku podeszłym”. Uczestniczyłem kiedyś w konferencji andragogicznej w Uniwersytecie Komeńskiego w Bratysławie. Tamtejsi andragodzy podjęli uchwałę o zarzucenia terminu „staroba” z powodu jego pejoratywnego wydźwięku.

Pani Profesor, i jeszcze jedno pojęcie. Zna Pani mój pogląd na ten temat. Chodzi o „szkolenie”, całkowicie nadużywane. Pojawiają się też pojęcia od niego pochodne: „doszkalać”, „przeszkalać” i in. Terminem tym posługujemy się błędnie. Prawdopodobnie wywiódł się on z terminu niemieckiego "Schulung”, oznaczającego chodzenie do szkoły, czy scholaryzacji, oznaczającej wskaźnik zagęszczenia szkół lub wskaźnik uczęszczania do nich. U nas zastępujemy nim tak fachowe pojęcia jak „kształcenia” „dokształcanie” i „doskonalenie”. Być może opracowanie dobrego słownika terminologicznego z zakresu teorii oświaty dorosłych zmieni tę sytuację. Zachęcam Panią i innych andragogów Pani pokolenia do realizacji tego przedsięwzięcia.

\section{Zainteresowania}

Droga Pani Profesor, pyta Pani o moje zainteresowania (pozazawodowe rozumiem). No cóż, w naszym zawodzie można je mieć, ale czy jest czas na ich realizację. Pochodzę z rodziny sportowej. Jedni to piłkarze (w różnych klu- 
bach). Drudzy, ci w Krynicy, to hokeiści (KTH). Sam w młodości uprawiałem kolarstwo. Do czasu gdy na jednym z wyścigów (a miałem wtedy 17 lat) nie skrzywdzili mnie sędziowie. Na trasie wyścigu „uciekłem” z głównego peletonu do przodu. Na jednej z sądeckich ulic, około 2 kilometrów przed metą, z powodu złego zabezpieczenia trasy przez organizatorów, z bocznej ulicy „doskoczył” do mnie jakiś pijany rowerzysta, coś przy tym bełkocząc na temat swoich możliwości kolarskich. Nie zdążył nawet ze mną się zrównać. Rozpędzony dotarłem do mety obstawionej widzami. Po dojechaniu następnych zawodników sędzia główny, a był nim J.K., ówczesny przewodniczący Powiatowego Komitetu Kultury Fizycznej, ogłosił wyniki przyznając, że wyścig wygrałem, ale z powodu korzystania z pomocy innego zawodnika zostaję zdyskwalifikowany. Na późniejsze protesty świadków wspomnianego incydentu sędzia główny nie zareagował. Na tym skończyło się moje startowanie, bo i tak na ściganie się wyczynowe nie miałem czasu ani odpowiedniego roweru. Podczas studiów zafascynował mnie chór akademicki UJ (prowadzony przez Stanisława Hasa). Uczęszczałem na jego próby, „szło” mi nawet nieźle. W miarę jednak jak przybywało mi lat tęskniłem coraz mocniej do tego, by zobaczyć inne kraje. Nie miałem żadnych możliwości zaspokojenia tej aspiracji. Sytuacja się zmieniła, gdy w 1972 r., kosztem dużego wysiłku finansowego, kupiłem (na przetargu w P. Z. Mot., bo talon na nowy samochód wtedy był dla mnie nie do osiągnięcia) używaną skodę. Mimo częściowego zużycia miała dwie zalety: mało paliła i nie psuła się.

Jeszcze w tym samym 1972 r., korzystając z zaproszenia kolegi moich rodziców, pojechaliśmy z żoną i kuzynem Zdzisławem do Paryża. Znajomy zabrał nas z sobą do Hiszpanii. Nie mogłem powstrzymać zachwytu tym pięknym krajem i jego budowlami. Wracając z Paryża zobaczyliśmy w Monachium zmagania olimpijskie, po tym zwiedziliśmy Salzburg, Wiedeń i Bratysławę. W latach następnych objechaliśmy Włochy, Skandynawię, Grecję, Turcję i ponownie Hiszpanię ,a nawet Portugalię (gdzie w Lizbonie uczestniczyłem w konferencji ISHE - jaki jedyny, który z tak daleka nie przyleciał samolotem). Nie byłem tylko w Islandii i Wielkiej Brytanii (poznałem ją przy okazji pobytu na konferencjach w Exeter i Dundee), bo nie dało się do nich dojechać samochodem. Gdy poznaliśmy Europę zaczęliśmy z żoną Anną latać (ze względu na zajęcia w Uniwersytecie wyłącznie w czasie wakacji) na organizowane wycieczki turystyczne. Tym sposobem w ciągu kilkunastu lat poznaliśmy główne kraje świata: od Kanady po Chile, od Egiptu do Republiki Południowej Afryki i od Japonii po Nowa Zelandię. Poznawaliśmy tam w pierwszym rzędzie gmachy i biblioteki znaczniejszych uczelni wyższych (bo tylko to można zobaczyć w miesiące wakacyjne), znane i typo- 
we dla poszczególnych krajów muzea, słynne obiekty sportowe (m.in. Maracana, Azteca, Nuovo Camp), świątynie i obiekty sakralne, miejsca bitew i tereny znane $z$ innych ważnych wydarzeń. Te wędrówki (choć niektóre należały do nieudanych z powodu nieprzygotowanych i nieodpowiednich przewodników) sprawiły, że dziś mam poczucie satysfakcji i dowartościowania, a obserwacje na nich poczynione często wykorzystywałem i wykorzystuję na zajęciach dydaktycznych za studentami, zachęcając ich do podróżowania. Żałuję tylko tego, że kraj nasz za późno jak na czas mojego życia stworzył korzystne warunki (układy z Schengen, ruch bezwizowy, wymienialność waluty, połączenia lotnicze nawet $z$ odległymi krajami) do kształcenia się przez podróżowanie. Cóż, na pewno lepiej późno niż wcale.

\section{Żona Ania}

O żonie Annie chciałoby się mówić długo. Co tu powiedzieć, by mówiąc nie popaść w stan euforii, a w miarę trafnie wskazać na niebiańskość tego Człowieka. Zobaczyłem Ją pierwszy raz w bibliotece jednej z uniwersyteckich katedr. Jeszcze się uczyła. Z tego powodu ślub odłożyliśmy o prawie rok. Początkowo pracowała w różnych szkołach ucząc biologii i przysposobienia do życia w rodzinie (w klasach żeńskich). Ostatnią szkołą było Technikum Odzieżowe przy ul. Syrokomli (w Szkole tej wcześniej pracowała Profesor Kazimiera Korabiowska-Nowacka). Zasłużyła na szacunek dyrekcji i uznanie młodzieży, uzyskiwała też pochwały od rodziców uczniów. Po latach pracy w szkole, przeszła - za namową przyjaciółki - do Wydziału Zatrudnienia w Urzędzie Miasta Krakowa, gdzie zajmowała się warunkami pracy i adaptacją zawodową młodych pracowników po szkołach zawodowych i studiach wyższych. Na tle tej pracy dochodziło niekiedy do sytuacji zabawnych. Gdy miejsce Jej pracy odkryli moi uniwersyteccy magistranci, natychmiast po zdaniu egzaminu magisterskiego przychodzili do Niej: informowali kim są, od kogo i po co przychodzą. W Wydziale Zatrudnienia zaczęły się nawet pojawiać żarty na ten temat. Najbardziej lubował się w nich Dyrektor Wydziału, ale w sprawie życzliwie pomagał. Tym sposobem moi uniwersyteccy wychowankowie, zwłaszcza pochodzący z Krakowa, nigdy nie pozostawali bez pracy.

Przy jakimś zebraniu z absolwentami studiów zainteresowanymi wejściem na rynek pracy poznała się z profesorem Janem Kulpą - dyrektorem Instytutu Pedagogiki WSP, który namówił ją na przejście do tej Uczelni. Chcąc pokazać najbliższym, co potrafi, przeszła bez dłuższego zastanawia- 
nia się. Szybko uzyskała doktorat w oparciu o rozprawę na temat motywów i okoliczności zmiany pracy młodych zatrudnionych. Doskonale wdrożyła się w wir życia akademickiego. W krótkim czasie wypromowała około 400 magistrów pełniąc równocześnie (z wyboru) funkcję zastępcy dyrektora Instytutu. Zmęczona nadmiarem pracy przeszła na wcześniejszą emeryturę z myślą zajęcia się domem.

W domu: Człowiek Anioł, bez pomocy którego pewnie dawno bym zginął (by nie powiedzieć dosadniej), wyjątkowo spolegliwy. Wszystko Jej zawdzięczam. Mężczyzna - mówię o sobie - to stworzenie czasem rażąco nieporadne, wymagające stałej pomocy. Znałem uczonych, którym żony kartki w kalendarzu przewracały mówiąc: dziś masz iść tu, a jutro tam i tam. Wyjątkowa nieporadność i nieudolność. Przerażające safanduły. Kobiety są inne, a moja Ania wyjątkowa.

\section{Róbmy swoje!}

Pyta mnie Pani o maksymę życiową, o wartości... Najważniejsza dla każdego jest rodzina. Zdrowie i rodzina.

A inne maksymy? Ucz się człowieku stale. Ale najchętniej powiedziałbym: Ano, róbmy swoje! Jak się zabraliśmy do jakiejś pracy, róbmy to uczciwie, spokojnie, doprowadzając do końca. I jeszcze jedna: nie lekceważyć szczegółów! Co prawda ludzie mówią, nie przejmuj się w życiu detalami, ale w nauce trzeba się przejmować detalami. Wiele rzeczy ukrywa się w nauce za szczegółami. Poszukiwanie szczegółów naprowadza na prawdę niedostępną w zastanych opracowaniach, otwiera całe obszary niewyczytanej wiedzy.

\section{Bibliografia}

Aleksander T. (2013), Andragogika, Podręcznik akademicki, Instytut Technologii Eksploatacji - PIB, Radom-Kraków, wyd. 2.

Aleksander T. (1968), Awans oświatowy młodzieży wiejskiej, LSW, Warszawa.

Aleksander T., Szarota Z. (2012), Tadeusz Aleksander w rozmowie z Zofiq Szarota: $O$ andragogice: $z$ przeszłości $w$ przyszłość, „Edukacja Ustawiczna Dorosłych”, nr 1, s. 45-49.

Aleksander T. (1974), Uwarunkowania uczestnictwa kulturalnego ludności wiejskiej, PWN, Warszawa. 
Aleksander T. (1993), Życie społeczne i przemiany kulturalne Nowego Sącza w latach 1870-1990, Oficyna Literacka, Kraków 1993.

Bron A. (2009), Biograficzność w badaniach andragogicznych, „Dyskursy Młodych Andragogów", t. 10, s. 37-54.

Demetrio D. (2000), Autobiografia. Terapeutyczny wymiar pisania o sobie. Przekład A. Skolimowska. Przedmowa O. Czerniawska, Impuls, Kraków.

Edukacja dorosłych jako czynnik rozwoju społecznego (materiały I Ogólnopolskiego Zjazdu Andragogicznego - Kraków, 23-24 czerwca 2009), t. 1 i 2, red. T. Aleksandra, Radom, Wydawnictwo Naukowe Instytutu Technologii Eksploatacji PIB, 2010.

Góralska R. (2014), „Nauczyciele potrafiq rozmiłować w swoim przedmiocie...” - pedagogiczne refleksje we wspomnieniach Mistrza, „Rocznik Andragogiczny”, s. 33-48.

Olejarz M. (2016), „Żyć w zgodzie ze sobq̨...”. Profesora Józefa Kargula opowieści (auto) biograficzne, „Rocznik Andragogiczny”, s. 47-64.

Solarczyk-Szwec H. (2015), Cztery ćwiartki biograficznego uczenia się, „Rocznik Andragogiczny", s. 119-133.

Szarota Z. (2012), Łemkowie. Rekonstrukcja tożsamości etnicznej, [w:] Oświata dorosłych wobec jednostek i grup defaworyzowanych. Ku społecznej jedności, red.

Z. Szarota, Wydawnictwo Naukowe Uniwersytetu Pedagogicznego, Kraków, s. $158-173$.

Szczepanowski S. (1888), Nędza Galicyi w cyfrach i program energicznego rozwoju gospodarstwa krajowego, Gubrynowicz i Schmidt, Lwów.

Woźnicka E. (2015), „Urzekli mnie moi uczniowie...”- osobiste refleksje we wspomnieniach Profesor Olgi Czerniawskiej, „Rocznik Andragogiczny”, s. 22-38.

Zierkiewicz E. (2016), „Nauka i uczenie się zawsze traktowane były przeze mnie priorytetowo..." - osobiste refleksje we wspomnieniach Profesor Alicji Kargulowej, „Rocznik Andragogiczny”, s. 21-39.

\section{Netografia}

Jarosiński M., Akcja „Wisła”, dostępne na: http://dzieje.pl/aktualnosci/akcja-\%E2\%80\%9Ewisla\%E2\%80\%9D [data publikacji 16.06.2009, data aktualizacji 7.10.2017, otwarcia wielokrotne]

mb, Akcja „Wisła” - wysiedleni z Bieszczad, Polskie Radio, dostępne na https://www. polskieradio.pl/39/156/Artykul/1108414,Akcja-Wisla-\%e2\%80\%93-wysiedleni-z-Bieszczad_[ostatnia aktualizacja 28.04.2017, otwarcia wielokrotne] 